\title{
Remittances, Liquidity Constraints and Human Capital Investments in Ecuador
}

\author{
Carla Calero León ${ }^{\mathrm{a}}$, Arjun S. Bedi ${ }^{\mathrm{b}}$ and Robert Sparrow ${ }^{\mathrm{b}}$ \\ ${ }^{a}$ Ministerio de Coordinación de Desarrollo Social, Quito, Ecuador \\ ${ }^{\mathrm{b}}$ Institute of Social Studies, The Hague, The Netherlands
}

March 2007

Preliminary draft-Comments welcome

\begin{abstract}
Over the last decade Ecuador has experienced a strong increase in financial transfers from migrated workers, amounting to 6.4 percent of GDP and 31.5 percent of total exports of goods and services in 2005. This paper investigates how remittances affect human capital investments through relaxing resource constraints and facilitate households in consumption smoothing by reducing vulnerability to economic shocks. In particular, we explore the effects of remittances on school enrolment and child work in Ecuador. Identification relies on instrumental variables, exploiting information on source countries of remittances and regional variation in the availability of bank offices that function as formal channels for sending remittances, reflecting transfer costs. Our results show that remittances increase school enrolment and decrease incidence of child work, especially for girls and in rural areas. We further find that aggregate shocks are associated with increased work activities, while remittances are used to finance education when households are faced with these shocks. This suggests that liquidity constraints and vulnerability to covariate risk are especially relevant in rural areas, as it affects household's investments in human capital of school age children. In this context both child labour and remittances function as coping mechanisms.
\end{abstract}

JEL Classification: I20, J22, O15

Keywords: Migration, remittances, school enrolment, child labour, Ecuador

Correspondence: Robert Sparrow, Institute of Social Studies, P.O. box 29776, 2502 LT The Hague, The Netherlands. Email: carlacalero@mcds.gov.ec (C.Calero León), bedi@iss.nl (A.S. Bedi), sparrow@iss.nl (R. Sparrow). 


\section{Introduction}

Ecuador has experienced a strong increase in financial transfers from migrated workers abroad during the last decade. Since 1999 these resource flows constitute the second largest source of foreign income in Ecuador after oil exports, amounting to 6.4 percent of GDP in 2005. Despite the magnitude of this remittance inflow there is relatively little empirical research that examines the role of remittances on the economy of Ecuador and livelihoods and behaviour of remittance receiving households.

In general, the literature on international migration and remittances does not provide an unambiguous picture on the outcomes for the receiving economy. A number of studies point out negative effects of remittances as they may discourage labour supply and effort of recipient households (Funkhouser, 1992) or finance current consumption promoting dependency of receiving countries (e.g. Taylor et al., 1996a and 1996b). On the other hand, more recent empirical evidence emphasizes the role of remittances in encouraging economic growth and development by enabling recipients to overcome liquidity constraints and finance productive investments (see Rapoport and Docquier, 2006, for an extensive literature review).

This paper follows the latter line of research as we scrutinise the potential role of remittances in human capital accumulation in Ecuador. Resource constraints and imperfect capital markets play a notable role in households' decisions concerning investment in children's human capital in Ecuador (e.g. Moser, 1996, Vos and Ponce, 2004). By reducing financial constraints, remittances can promote schooling investment and increase child reservation wages, thereby reducing children's labour force participation. In addition, trans-national social networks provide income diversification strategies and alternative coping mechanisms for consumption smoothing, through remittances, in response to economic shocks. In the context of 
imperfect financial markets, investments in human capital are typically compromised by income variability (e.g. Beegle, Dehejia and Gatti, 2003, Dehejia and Gatti, 2002, and Jacoby and Skoufias, 1997).

Several studies have found evidence that remittances are associated with increased educational attainment and reduction in child labour supply. For example for El Salvador, Acosta (2006) finds that girls and boys under 14 years old from recipient families are more likely to attend school than those from non-recipient households, while Cox-Edwards and Ureta (2003) show that school dropout hazard rates are reduced by remittances. Hanson and Woodruff (2002) find that remittances have a positive effect on education outcomes in Mexico for girls aged 10 to 15 with mothers with a very low level of education. Borraz (2005) finds similar results using data from the Mexican census, which suggest a positive but small effect on schooling for boys and girls with low educated mothers and who reside in cities with less than 2,500 inhabitants. Yang and Martínez (2005) find declines in child labour supply with households whose migrant members experience favourable exchange rate shocks in the Philippines.

However, other findings present mixed results of the effect of remittances on child schooling. McKenzie and Rapoport (2006), for example, find a negative effect on schooling attendance and education attainment among 16-18 year old girls and 1218 year-old boys, but a positive effect for younger girls with uneducated mothers in rural Mexico. They attribute these outcomes to side effects of migration. For instance, the absence of parents in the household due to migration could lead to reduced investment in their children's education and an increase of child work incidence. López-Córdoba (2004) shows that these effects are especially relevant for secondary school age children in Mexico, as remittances positively affect school attendance for 
children aged 6 to 14, but negatively for boys and girls aged 15 to 17. In a study on 11 Latin American countries, Fajnzylber and López's (2006) find that only 6 in countries in the region (Nicaragua, Guatemala, Honduras, Ecuador, Haiti, and El Salvador ) children from remittance-receiving households are more likely to attend school, the effect being larger for children with mothers with low level of education.

Caution is required when interpreting estimated effects of remittances on school enrolment and child work as causal relations because of the endogenous nature of remittances. Most of the studies cited above claim identification of causal effects by virtue of instrumental variables constructed from historical migration rates (i.e. Acosta, 2006, Fajnzylber and López, 2006, Hanson and Woodruff, 2002, and McKenzie and Rapoport, 2006).

In this paper, identification relies on instrumental variables that exploit information on source countries of remittances and regional variation in the availability of bank offices that function as formal channels for sending remittances. These instruments capture information on transfers costs and accessibility to channels of transmission, which partly determine the volume and frequency of funds transferred, while they are not expected to affect school enrolment and child labour.

Our results suggest that remittances increase school enrolment and decrease incidence of child work, especially for girls and in rural areas of Ecuador. We further find that aggregate shocks are associated with increased work activities, while remittances are used to finance education when households are faced with these shocks. This suggests that liquidity constraints and vulnerability to covariate risk are especially relevant in rural areas, as it affects household's investments in human capital of school age children. In this context both child labour and remittances function as coping mechanisms. 
The paper is organized as follows. The next section describes the data used in the analysis, while section 3 illustrates the context of education, migration and remittances in Ecuador. Our empirical strategy is set out in section 4 and the results are presented and discussed in section 5. Section 6 concludes.

\section{The data}

Our analysis draws on a nationally representative living standard household survey for Ecuador from 2005/2006, Encuesta Condiciones de Vida - Quinta Ronda (ECV). The ECV covers a wide range of socioeconomic indicators for households and individuals, including school attendance and work activities in the previous week. We focus on work activities that contribute to household income, for which information is collected for children 10 years and older. Information on remittances includes the size of cash transfers received from abroad, the country where the remittances come from and how they were spent (e.g. construction, investment, non-durable consumption, food, housing, education and health care). The survey also asks questions regarding unexpected events and shocks that have affected households' income during the last year. These include idiosyncratic shocks such as severe illness, accidents or death of a household member, and covariate shocks such natural disasters, droughts, insect plagues and unexpected periods of frost.

The 2005/2006 survey includes 55,666 individuals from 13,581 households and is representative at the province level. We restrict our analysis to a sample of 8,600 children age 10 to 17 of which 14 percent live in a household that receives

remittances. Table 1 presents descriptive statistics for the sample separately for children from recipient and non-recipient households. There are some distinct differences between remittance receiving households and non-recipient households. 
Amongst recipient households adults have a higher level of education and the head of household is more likely to be female. Remittance-receiving households are on average smaller and have more access to electricity, water, in-house sanitation and telephone.

\section{Education, child work and remittances in Ecuador}

\section{Migration and remittances}

Over the last decade Ecuador experienced a large international out-migration motivated primarily by economic factors. The financial and foreign exchange crisis during 1999 and the dollarization process in 2000 severely deteriorated living standards and disrupted labour markets. GDP declined from 23,255 million dollars in 1998 to 16,674 million dollars in 1999 , and GDP per capita fell by $30 \%$. The unemployment rate increased dramatically, peaking at $14.4 \%$ in 1999 . Poverty rates increased from $34 \%$ before the crisis to $71 \%$ in 2000 (Acosta et al., 2005). As a result a large number of Ecuadorians left the country to find work opportunities elsewhere (Acosta et al., 2004 and 2005, Ramírez and Ramírez, 2005). According to the InterAmerican Development Bank (2006) an estimated one million Ecuadorians migrated to Spain, United States and other countries in Central America between 2000 and 2005. Spain is the main migration destination, accounting for about half a million Ecuadorian migrants (Inter-American Development Bank, 2006).

The most visible economic consequence of this out migration wave is the substantial and increasing amount of monetary transfers that Ecuadorian migrants have been sending back. Figure 1 shows estimates by the Central Bank of Ecuador of the volume of remittance inflow from 1996 to 2005 . Over that period remittances have grown at an average rate of 19 percent and since 1999 constitute the second 
largest source of foreign income after oil exports, exceeding official development aid and foreign direct investment. In 2005 remittances reached a total of 2,318 million dollars, which amounts to 6.35 percent of GDP and 31.5 percent of total exports of goods and services (Central Bank of Ecuador).

According to the ECV 2005/2006 about 16 percent of the Ecuadorians live in a household that receives international transfers (Table 2). On average these households received US\$28.83 per capita in the last year. Three quarters of these households reside in urban areas and almost all live in the Sierra and Costa regions. This is due to higher incidence of remittances in these areas, but for the most part due to population size. The bulk of remittance flows goes to middle and higher income households. The richest 40 percent of the population account for more 57 percent of recipients, while 22 percent of recipients come from the poorest 40 percent of the population. The latter group roughly represent those that live below the poverty line. ${ }^{1}$ The amount received also strongly increases with overall level of consumption. The average remitted amount per capita (i.e. per head of the receiving household) is four times larger for the richest quintile compared to the poorest.

Recipient households report that they use income from remittance mainly for education, food, health and rent $(89.4 \%){ }^{2}$ The remainder is said to go to construction and properties investments (3.1\%), settlement of debts (2.9\%), savings (1.2\%), business investments (1.2\%), household assets such as fridges, stoves and laundry machines $(0.9 \%)$, acquisition of vehicles $(0.3 \%)$ and other forms of consumption $(1.0 \%)$. Interestingly, these reported spending patterns do not differ much between urban and rural households, although households in rural areas use a higher percentage of

\footnotetext{
${ }^{1}$ In 2005 the poverty headcount for Ecuador is estimated at 38 percent, and severe poverty at 12 percent. The quintiles in Table 2 are based on per capita consumption.

${ }^{2}$ Unfortunately the data does not allow use to decompose this further to the different types of expenses.
} 
remittances for the acquisition of household assets and reserve a smaller share for savings.

Table 3 shows the remittance flow reported for the last 12 months by source country. ${ }^{3}$ As expected, the main destinations of Ecuadorians migrants are the most important countries of origination. More than half of the recipients receive transfers from Spain, while 35.4 percent receive funds from the United States, 9.8 percent from Italy, 2.1 percent from the Andean Community countries and 4.5 percent from other countries. In terms of total volumes, Spain is the main source with the USA a close second. The amount of remittances originating from Spain is due to the large number of Ecuadorian migrants, but not the size of the transfers, as remittances from Spain are relatively small on a per capita basis. Remittances by Ecuadorians working in the Andean Community countries are small in frequency but relative large in average amount.

\section{Education and child work}

From 1995 to 2005 school enrolment and attendance in Ecuador improved for all school levels. Primary schooling in Ecuador starts at 6 until 11 years, with secondary school age typically being 12 to 17 years. Table 4 shows the net school attendance rate (in the previous week) for primary schooling increasing from 89 percent in 1995 to 94.2 percent in 2005 , while net secondary school attendance increased from 49.7 to 55.4 percent. Enrolment is higher in urban areas but the urban-rural gap has decreased strongly. Gender disparities are small and have also decreased over time.

With increased school attendance, Table 5 shows that child work has decreased from 1995 to 2005 . The table reports incidence of economic work

\footnotetext{
${ }^{3}$ The survey classifies source countries as Spain, United Sates, Italy, Andean Community countries (Colombia, Bolivia, Peru and Venezuela) and others countries.
} 
activities, excluding domestic work. In 2005 about a quarter of 15 to 17 year olds work and do not go to school, and another 27.8 percent combines work and schooling. During the crisis in 1999 incidence of child work increased for the children younger than 14 , while there was little change for secondary school aged children.

In this paper we will look at the effect of remittances on school enrolment as it is a better reflection of the household's investment decision than school attendance, given the fixed costs that are associated with it (e.g. school enrolment fees). Table 6 shows average school enrolment and work incidence for boys and girls in the ECV 2005/2006 sample. Remittances seem to be associated with higher enrolment and lower incidence of child work, both domestic and non-domestic work. This trend is not consistent with the idea that parental absence as a consequence of migration may demand children to undertake domestic tasks (Mckenzie and Rapoport 2006).

\section{Empirical approach}

\section{Empirical specification}

To estimate the impact of remittances on human capital investments we take a reduced form approach, where we model the probability of being enrolled in school or participating in income generating activities as a function of remittance transfers, individual and household characteristics, and regional labour market and economic conditions. The absolute amount of remittances received per capita during the last year is our main explanatory variable of interest. Note that in the analysis we are ignoring the migration decision itself and only focus of the marginal effects of international transfers on schooling and labour supply. The disadvantage of this approach is that we do not analyse to what extent international migration is an integral part of a household's income diversification strategy. Instead, we treat remittance 
transfers as outcomes of existing trans-national networks. Thus, we do not identify the effects of migration but we examine the role of trans-national networks in consumption smoothing, relaxing liquidity constraints and human capital investments.

We do not include income or household expenditures as covariates as they are directly affected by the outcome variables. Instead, we treat the household characteristics as proxies for socio-economic status of the household. For individuals we control for age and gender, while household characteristics include information on the head of households (gender, marital status), education level of highest educated males and females, household size and living conditions (home ownership, type of floor and sanitation, and access to electricity, telephone and clean water).

The ECV collects information on idiosyncratic and covariate shocks to household income. In particular the latter are expected to affect human capital decisions as both market based and informal insurance and coping mechanisms may break down under aggregate shocks (e.g. Glewwe and Hall, 1998, Jacoby and Skoufias, 1997, Morduch, 1995 and 1999, Skoufias, 2003). It is here that transnational networks and remittances can play an important role as informal safety nets, as they transcend country specific developments. We consider several types of exogenous shocks that household may be exposed to: a member of the household has recently been severely ill, had an accident or died (idiosyncratic shocks), droughts, insect plagues or crops affected by frost (covariate shocks). The remittance recipients in our sample are more likely to experience idiosyncratic shocks but are less exposed to covariate shocks (see Table 1).

Since labour supply, schooling and remittances may all be driven by regional specific labour market and economic characteristics, we control for the poverty headcount and unemployment rate in the province where the child lives, and the 
urban-rural composition and average age of the province population. In addition, we include dummy variables for the three main geographic areas of Ecuador: Sierra, Costa and Amazonia.

\section{Identification}

Remittances received by households are potentially endogenous to human capital decisions and child labour supply. This can be due to, for example, unobserved heterogeneity associated with both presence of trans-national networks and schooling decisions, or to income shocks affecting human capital investments and labour supply while simultaneously adjusting remittances to reduce income volatility. There may even be direct reverse causality if households consider migration and remittances as an explicit means of funding education of their children.

Historical migration rates have been used as instrumental variables for current migration (often interacted with household characteristics) in a number of studies (e.g. Acosta, 2006, Fajnzylber and López, 2006, Hanson and Woodruff, 2002, and McKenzie and Rapoport, 2006). Justification of this instrument lies with sociological literature that argues that trans-national social networks promote migration of other household members. Thus, historical migration patterns partly determine current migration rates. However, this instrument is not suitable for the amount of remittances because having migrated household members in the past does not explain variation in the amount of remittances amongst remittance receiving households (McKenzie, 2005).

In this paper we identify causal effects of remittances by virtue of instrumental variables constructed form exogenous variation in transaction costs of international financial transfers. Two sources of information reflect these transaction costs: the 
source countries of the remittances received and (following Amuedo-Dorantes and Pozo, 2006) regional variation in availability of Western Union bank offices that function as formal channels for sending remittances. Both these instruments capture information on transfers costs and accessibility to channels of transmission, which partly determine the volume and frequency of funds transferred. At they same time they are not expected to affect school enrolment and child labour supply. The variation in Western Union branches across provinces is shown in Table 7. Availability of Western Union branches per province is interacted with all source country dummy variables as to fully exploit the variation in the instruments and increase support for identification.

\section{Results}

The determinants of school enrolment and child work are given in Table 8. The table reports IV probit coefficients for the full sample of 8,600 children age 10 to 17 . The instruments are jointly significant at a 1 percent level. The IV probit approach takes a linear specification for the first stage regression. We investigated the support of the instruments further by estimating the first stage equation as tobit in addition to a probit analysis of the probability of remittance receipt. ${ }^{4} \mathrm{We}$ find that the Western Union variable is a strong determinant for the probability of receiving remittances but to a lesser extent for the amount sent. The country dummy variables are highly significant for the amount remitted. These results suggest that the instruments combined, and with interaction terms, provide strong support for identification of the effects of remittances. We also estimated a linear probability specification in order to perform a Sargan over-identification restrictions test. For both school enrolment and

\footnotetext{
${ }^{4}$ First stage estimates are not shown here but are available upon request.
} 
work the validity of the instruments was not rejected $\left(\chi^{2}\right.$ test statistics of 15.889 and 11.912, respectively, with 10 degrees of freedom).

The associated marginal effects for per capita remittances and shocks are reported in the first columns of Table 9 (enrolment) and Table 10 (work). The remaining columns in these tables show the results for different sub-samples: male/female, urban/rural and non-poor/poor.

Remittances are used to finance schooling, in particular that of girls, children in rural areas and amongst the poor. While remittances increase school enrolment amongst the poor, this is not the case for the non-poor. This suggests that investments in human resources amongst the poor are bound by resource constraints. At the same time we find that remittances reduce incidence of child work only amongst the nonpoor and in rural areas, suggesting that reservation wages are higher for the non-poor compared to the poor. Thus, while remittances may increase human capital investments amongst the poor, they are not sufficient to offset earnings from child labour.

Shocks do not seem to have any effect on schooling, but they do have implications for child work. Especially exposure to covariate shocks increases incidence of child labour. The effects are relatively large for girls, in rural areas and children from poor households. This is consistent with the notion that alternative insurance mechanisms are less effective in poor rural environments, hence a relatively larger role for child labour as contingency asset.

Probing the role of trans-national networks and remittances, we estimated the model for sub-sample of children that were exposed to certain shocks and those 
that were not. ${ }^{5}$ The results are given in Table 11 . We find no evidence that remittances reduce the pressure on households to draw on their child labour. This is somewhat surprising since the probability of work is sensitive to economic shocks. However, we do find that remittances are used to finance education when households are faced with these shocks, while schooling itself did not seem sensitive to shocks. For all type of shocks the effects of remittances is significantly larger for children if their household experienced a shock compared to households that did not.

This evidence suggests that education is indeed partly financed by international remittances, and that reducing investment in children's education is generally not considered as a coping mechanism by households when faced with unexpected income shocks; at least not in the short term. In fact, remittances serve as insurance mechanism in order to maintain school enrolment in response to these shocks.

Child work, on the other hand, seems sensitive to shocks, but not affected by remittances. In other words, shocks drive households to fall back on child labour, while remittances are generally not high enough to increase reservation wages such that it reduces child work (except for the non-poor), irrespective of the households exposure to risk. This would suggest that, like trans-national networks, child labour is just one alternative for consumption smoothing.

\section{Conclusion}

In this paper we analyse the role of remittances in human capital accumulation in Ecuador, which has experienced a strong increase in financial transfers from migrated workers abroad during the last decade. We explore how remittances affect human

\footnotetext{
${ }^{5}$ We initially experimented with interaction terms of remittances and shock, but our results were sensitive to specification. The more flexible approach, by estimating the effects for different sub samples, was robust to choice of instruments.
} 
capital investments through relaxing resource constraints and facilitate households in consumption smoothing by reducing vulnerability to economic shocks. In particular, we explore the effects of remittances on school enrolment and child work in Ecuador.

Identification relies on instrumental variables, which exploit information on source countries of remittances and regional variation in the availability of bank offices that function as formal channels for sending remittances. These instruments capture information on transfers costs and accessibility to channels of transmission, which partly determine the volume and frequency of funds transferred, while they are not expected to affect school enrolment and child labour. Over-identifying restrictions tests confirm validity of the instruments.

Our results show that remittances increase school enrolment, in particular for girls and in rural areas. To a lesser extent remittances also reduce child labour supply. We further find that especially aggregate shocks are associated with increased work activities. Schooling, on the other hand, does not seem sensitive to shocks, suggesting that households employ other coping mechanisms rather than compromise human capital investments.

Not only do remittances provide a structural source for human capital investments, trans-national networks also function as insurance mechanism, as we find that remittances are used to maintain education when households are faced with economic shocks. This suggests that liquidity constraints and vulnerability to covariate risk are relevant for human capital accumulation of school age children, especially in rural areas. Within the context of uncertainty both child labour and remittances function as informal insurance coping mechanisms. 


\section{References}

Acosta, P. (2006) "Labor Supply, School Attendance, and Remittances from International Migration: the Case of El Salvador", World Bank Policy Research Working Paper 3903, Washington D.C.

Acosta, A., S. López, and D. Villamar (2004) "Ecuador: Oportunidades y Amenazas Económicas de la Emigración”, in F. Hidalgo (ed.) Migraciones: un juego con cartas marcadas, pp. 259-301. Quito: Abya-Yala and Instituto Latinoamericano de Investigaciones Sociales.

Acosta, A., S. López, and D. Villamar (2005) "Las remesas y su aporte para la economía ecuatoriana", in G. Herrera, M. Carrillo and A. Torres (eds) La Migración Ecuatoriana: Transnacionalismo, Redes e Identidades, pp. 227-252. Quito: FLACSO-Ecuador.

Amuedo-Dorantes, C. and S. Pozo (2006) "Migration, Remittances, and Male and Female Employment Patterns”, American Economic Review 96(2), pp. 222-226.

Beegle, K., R. Dehejia, and R. Gatti (2003) “Child Labor, Income Shocks, and Access to Credit”, World Bank Policy Research Working Paper 3075, Washington D.C.

Borraz, F. (2005) “Assessing the Impact of Remittances on Schooling: The Mexican Experience", Global Economy Journal 5(1), pp. 1-30.

Cox. E. and M. Ureta (2003) "International Migration, Remittances, and Schooling: Evidence from El Salvador”, Journal of Development Economics 72, pp. 429-461.

Dehejia, R. and R. Gatti (2002) “The Role of Income Variability and Access to Credit in a Cross-Section of Countries", World Bank Policy Research Working Paper 2767, Washington D.C.

Fajnzylber, P. and H. López (2006) "Close to Home: The Development Impact of Remittances in Latin America”, conference edition, World Bank, Washington D.C. 
Funkhouser, E. (1992) "Migration from Nicaragua: Some Recent Evidence”, World Development 20(8), pp. 1209-1218.

Glewwe, P. and G. Hall (1998) “Are some groups more vulnerable to macroeconomic schocks than others? Hypothesis tests based on panel data from Peru", Journal of Development Economics 56(1), pp. 181-206.

Hanson, G. and C. Woodruff (2002) "Emigration and Educational Attainment in Mexico", mimeo, University of California San Diego.

Inter-American Development Bank (2006) "Remittances 2005: Promoting Financial Democracy”, Washington D.C.

Jacoby, H. and E. Skoufias (1997) "Risk, Financial Markets, and Human Capital in Developing Country", Review of Economic Studies 64, pp. 311-355.

López-Córdoba, E. (2004) “Globalization, Migration and Development: The Role of Mexican Migrant Remittances", forthcoming in Economia.

McKenzie, D. (2005) "Beyond Remittances: the Effects of Migration on Mexican Households", in C. Özden and M. Schiffff (eds) International Migration, Remittances and the Brain Drain, pp. 123-147. New York: World Bank and Palgrave Macmillan.

McKenzie, D. and H. Rapoport (2006) “Can migration reduce educational attainment? Evidence from Mexico", World Bank Policy Research Working Paper 3952, Washington D.C.

Morduch, J. (1995) "Income smoothing and consumption smoothing", The Journal of Economic Perspective 9(3), pp. 103-114.

Morduch, J. (1999) "Between the State and the Market: Can Informal Insurance Patch the Safety Net?" The World Bank Research Observer 14(2), pp. 187-207. 
Moser, C (1996) "Confronting Crisis: A Summary of Household Responses to Poverty and Vulnerability in Four Poor Urban Communities", ESD Studies and Monographs Series no. 7. Washington: World Bank.

Ramírez, F. and J. Ramírez (2005) "Redes transnacionales y repertorios de acción migratoria: de Quito y Guayaquil para las ciudades del Primer Mundo”, in G. Herrera, M. Carrillo and A. Torres (eds) La Migración Ecuatoriana: Transnacionalismo, Redes e Identidades, pp. 71-103. Quito: FLACSO-Ecuador.

Rapoport, H. and F. Docquier (2006) “The Economics of Migrants' Remittances”, in S. Kolm and J. Mercier (eds) Handbook of the Economics of Giving, Altruism and Reciprocity, pp. 1138-1195. Amsterdam: North Holland.

Skoufias, E. (2003) "Economic Crises and Natural Disasters: Coping Strategies and Policy Implications”, World Development 31(7), pp. 1087-1102.

Taylor, J., J. Arango, H. Graeme, A. Kouaouci, D. Massey, and A. Pelligrino (1996a) "International Migration and National Development", Population Index 62(2), pp. $181-212$.

Taylor, J., J. Arango, H. Graeme, A. Kouaouci, D. Massey, and A. Pelligrino (1996b) “International Migration and Community Development”, Population Index 62(3), pp. 397-418.

Vos, R. and J. Ponce (2004) "Meeting the Millennium Development Goal in Education: a Cost-Effectiveness Analysis for Ecuador", ISS Working Paper no. 402. The Hague: Institute of Social Studies.

Yang, D. and C. Martínez (2005) "Remittances and Poverty in Migrants' Home Areas: Evidence from the Philippines", in C. Özden and M. Schiffff (eds) International Migration, Remittances and the Brain Drain, pp. 81-121. World Bank and Palgrave Macmillan: New York. 


\section{Tables}

Table 1 Selected descriptive statistics, sample includes all children aged 10 to 17

\begin{tabular}{|c|c|c|c|c|}
\hline \multirow[t]{2}{*}{ Variables } & \multicolumn{2}{|c|}{ Non-recipients } & \multicolumn{2}{|c|}{ Recipients } \\
\hline & Mean & [s.d.] & Mean & [s.d.] \\
\hline School enrolment & 0.819 & {$[0.385]$} & 0.884 & {$[0.320]$} \\
\hline Work activities & 0.386 & {$[0.487]$} & 0.306 & {$[0.461]$} \\
\hline Per capita remittances & 0.000 & {$[0.000]$} & 23.082 & [40.505] \\
\hline Age & 13.272 & {$[2.265]$} & 13.512 & {$[2.307]$} \\
\hline Female & 0.479 & {$[0.500]$} & 0.490 & {$[0.500]$} \\
\hline Female head of household & 0.075 & {$[0.263]$} & 0.159 & {$[0.366]$} \\
\hline Head of household is married & 0.643 & {$[0.479]$} & 0.664 & {$[0.473]$} \\
\hline Highest educated female: none & 0.083 & {$[0.275]$} & 0.041 & {$[0.200]$} \\
\hline Highest educated female: primary & 0.479 & {$[0.500]$} & 0.316 & {$[0.465]$} \\
\hline Highest educated female: secondary & 0.289 & {$[0.453]$} & 0.421 & {$[0.494]$} \\
\hline Highest educated female: higher & 0.149 & {$[0.356]$} & 0.221 & {$[0.415]$} \\
\hline Highest educated male: none & 0.045 & {$[0.207]$} & 0.024 & {$[0.154]$} \\
\hline Highest educated male: primary & 0.470 & [0.499] & 0.347 & {$[0.476]$} \\
\hline Highest educated male: secondary & 0.326 & [0.469] & 0.395 & {$[0.489]$} \\
\hline Highest educated male: higher & 0.159 & {$[0.366]$} & 0.234 & {$[0.424]$} \\
\hline Household size & 6.196 & {$[2.265]$} & 6.047 & {$[2.115]$} \\
\hline Home owner & 0.752 & {$[0.432]$} & 0.747 & {$[0.435]$} \\
\hline Dirt floor & 0.116 & {$[0.320]$} & 0.062 & {$[0.241]$} \\
\hline Access to clean water & 0.548 & [0.498] & 0.764 & {$[0.425]$} \\
\hline Access to electricity & 0.918 & {$[0.274]$} & 0.983 & {$[0.130]$} \\
\hline In-house toilet & 0.744 & {$[0.436]$} & 0.894 & {$[0.308]$} \\
\hline Telephone & 0.259 & {$[0.438]$} & 0.494 & {$[0.500]$} \\
\hline Death, illness, accident & 0.143 & {$[0.351]$} & 0.236 & {$[0.425]$} \\
\hline Drought & 0.235 & {$[0.424]$} & 0.168 & {$[0.374]$} \\
\hline Frost & 0.171 & {$[0.377]$} & 0.138 & [0.345] \\
\hline Plagues & 0.216 & [0.412] & 0.111 & [0.315] \\
\hline Rural area & 0.533 & [0.499] & 0.384 & {$[0.487]$} \\
\hline Poverty headcount in district & 0.432 & {$[0.123]$} & 0.392 & [0.121] \\
\hline Unemployment rate in district & 0.110 & {$[0.045]$} & 0.121 & [0.043] \\
\hline
\end{tabular}




\begin{tabular}{lcccc} 
Rural population in district & 0.487 & {$[0.211]$} & 0.457 & {$[0.220]$} \\
Average age district & 26.959 & {$[1.743]$} & 27.168 & {$[1.546]$} \\
Sierra region & 0.517 & {$[0.500]$} & 0.548 & {$[0.498]$} \\
Costa region & 0.385 & {$[0.487]$} & 0.380 & {$[0.486]$} \\
Amazonia region & 0.098 & {$[0.297]$} & 0.072 & {$[0.258]$} \\
\hline Number of observations & 7,371 & & 1,229 &
\end{tabular}

Source: Encuesta Condiciones de Vida 2005/2006.

Table 2 Distribution of remittances during past year

\begin{tabular}{lccc}
\hline & $\begin{array}{c}\text { Incidence } \\
\text { (\% of population) }\end{array}$ & $\begin{array}{c}\text { Share } \\
\text { (\% of recipients) }\end{array}$ & $\begin{array}{c}\text { Average amount } \\
\text { (US\$ per capita) }\end{array}$ \\
\hline Quintile 1 (poorest) & 5.6 & 7.0 & 10.73 \\
Quintile 2 & 12.1 & 15.2 & 11.90 \\
Quintile 3 & 16.8 & 21.1 & 19.38 \\
Quintile 4 & 23.3 & 29.3 & 30.37 \\
Quintile 5 (richest) & 21.8 & 27.4 & 48.05 \\
Urban & 18.6 & 74.4 & 30.37 \\
Rural & 11.2 & 25.6 & 24.38 \\
Sierra & 16.9 & 48.2 & 32.20 \\
Costa & 15.5 & 48.7 & 25.84 \\
Amazonia & 10.3 & 3.1 & 23.58 \\
\hline Ecuador & 15.9 & 100.0 & 28.83 \\
\hline
\end{tabular}

Source: Encuesta Condiciones de Vida 2005/2006. 
Table 3 Source country and average size of remittances in past year

\begin{tabular}{lccc}
\hline Source country & Share of recipients & Transfer per capita & Total remittances \\
\hline Spain & $(\%)$ & $(U S \$)$ & (US\$) \\
USA & 51.54 & 25.89 & $26,773,019$ \\
Italy & 35.42 & 33.12 & $24,122,609$ \\
Andean Community & 9.84 & 30.95 & $4,771,111$ \\
Other countries & 2.08 & 39.01 & $1,703,870$ \\
\hline
\end{tabular}

Source: Encuesta Condiciones de Vida 2005/2006.

Table 4 Net school attendance rates by educational level, 1995-2005 (percentages)

\begin{tabular}{lllll}
\hline & 1995 & 1998 & 1999 & 2005 \\
\hline Primary education & & & & \\
Urban & 90.2 & 91.0 & 92.2 & 94.7 \\
Rural & 87.7 & 87.4 & 87.9 & 93.9 \\
Male & 88.1 & 88.3 & 90.2 & 94.4 \\
Female & 90.0 & 90.5 & 90.3 & 94.2 \\
Total & 89.0 & 89.4 & 90.3 & 94.3 \\
Secondary education & & & & \\
Urban & 64.8 & 68.2 & 66.6 & 64.2 \\
Rural & 28.9 & 35.2 & 30.2 & 41.3 \\
Male & 46.5 & 51.0 & 51.4 & 54.5 \\
Female & 52.9 & 54.9 & 51.5 & 56.3 \\
Total & 49.7 & 52.9 & 51.4 & 55.4 \\
\hline
\end{tabular}

Source: Encuesta Condiciones de Vida 1995, 1998, 1999 and 2005/2006. 
Table 5 Work activities and school attendance by age group, 1995-2005 (percentages)

\begin{tabular}{lcccc}
\hline & 1995 & 1998 & 1999 & 2005 \\
\hline Work only & 1.9 & 1.9 & 2.2 & 1.0 \\
$10-11$ & 16.4 & 13.5 & 13.8 & 11.7 \\
$12-14$ & 33.3 & 30.9 & 31.3 & 25.7 \\
$15-17$ & 19.0 & 17.1 & 17.0 & 13.6 \\
$10-17$ & & & & \\
School only & 71.0 & 72.5 & 70.8 & 78.0 \\
$10-11$ & 52.2 & 52.4 & 51.1 & 56.5 \\
$12-14$ & 37.4 & 32.6 & 35.3 & 41.2 \\
$15-17$ & 51.3 & 49.9 & 50.6 & 57.1 \\
$10-17$ & & & & \\
Work and school & 24.9 & 24.2 & 25.3 & 19.7 \\
$10-11$ & 25.9 & 28.7 & 30.1 & 27.9 \\
$12-14$ & 21.0 & 28.5 & 26.5 & 27.8 \\
$15-17$ & 23.8 & 27.5 & 27.6 & 25.6 \\
$10-17$ & & & & \\
\hline
\end{tabular}

Source: Encuesta Condiciones de Vida 1995, 1998, 1999 and 2005/2006. 
Table 6 School enrolment and work for remittance recipients and non-recipients aged 10 to 17 (percentages)

\begin{tabular}{lcccccc}
\hline & \multicolumn{3}{c}{ Remittance recipients } & \multicolumn{3}{c}{ Remittance non-recipients } \\
& Boys & Girls & All & Boys & Girls & All \\
\hline Enrolment & & & & & & \\
$10-11$ & 99.09 & 99.10 & 99.09 & 98.04 & 96.69 & 97.37 \\
$12-14$ & 90.63 & 91.99 & 91.29 & 84.45 & 81.44 & 83.05 \\
$15-17$ & 77.54 & 77.23 & 77.38 & 65.79 & 67.27 & 66.51 \\
$10-17$ & 87.89 & 88.23 & 88.06 & 81.92 & 80.91 & 81.43 \\
Work - non domestic & & & & & & \\
$10-11$ & 17.81 & 19.00 & 18.41 & 24.00 & 17.52 & 20.79 \\
$12-14$ & 33.84 & 27.88 & 30.95 & 45.44 & 34.10 & 40.16 \\
$15-17$ & 51.69 & 35.69 & 43.69 & 60.53 & 41.98 & 51.45 \\
$10-17$ & 36.46 & 28.55 & 32.54 & 44.68 & 32.10 & 38.62 \\
Work - domestic & & & & & & \\
$10-11$ & 11.42 & 17.19 & 14.32 & 15.54 & 14.65 & 15.10 \\
$12-14$ & 22.66 & 26.60 & 24.57 & 27.94 & 31.47 & 29.58 \\
$15-17$ & 34.15 & 32.62 & 33.38 & 33.93 & 38.01 & 35.93 \\
$10-17$ & 24.11 & 26.46 & 25.27 & 26.59 & 28.94 & 27.72 \\
\hline Source: Enckesta Condicis & & & & &
\end{tabular}

Source: Encuesta Condiciones de Vida 2005/2006. 
Table 7 Remittances and number of Western Union branches by province

\begin{tabular}{|c|c|c|c|}
\hline Province & $\begin{array}{l}\text { Western Union } \\
\text { branches }\end{array}$ & $\begin{array}{c}\text { Remittance } \\
\text { recipients (\%) }\end{array}$ & $\begin{array}{l}\text { Average amount } \\
\text { (US\$ per capita) }\end{array}$ \\
\hline \multicolumn{4}{|l|}{ Sierra region } \\
\hline Azuay & 17 & 30.0 & 43.40 \\
\hline Bolivar & 5 & 6.3 & 13.30 \\
\hline Canar & 6 & 47.0 & 38.36 \\
\hline Carchi & 2 & 3.0 & 13.15 \\
\hline Cotopaxi & 1 & 9.7 & 18.96 \\
\hline Chimborazo & 5 & 10.2 & 28.89 \\
\hline Imbabura & 3 & 11.0 & 18.37 \\
\hline Loja & 2 & 20.7 & 30.58 \\
\hline Pichincha & 30 & 15.2 & 30.95 \\
\hline Tungurahua & 5 & 16.6 & 23.58 \\
\hline Total & 76 & 16.9 & 32.20 \\
\hline \multicolumn{4}{|l|}{ Costa region } \\
\hline El Oro & 7 & 21.5 & 34.40 \\
\hline Esmeraldas & 3 & 9.8 & 21.97 \\
\hline Guayas & 33 & 17.9 & 25.96 \\
\hline Los Rios & 10 & 10.5 & 21.09 \\
\hline Manabi & 13 & 10.7 & 21.20 \\
\hline Total & 66 & 15.5 & 25.84 \\
\hline \multicolumn{4}{|l|}{ Amazonia region } \\
\hline Morona Santiago & 4 & 15.1 & 33.53 \\
\hline Napo & 1 & 8.0 & 31.78 \\
\hline Pastaza & 2 & 8.9 & 27.31 \\
\hline Zamora Chinchipe & 2 & 19.9 & 10.00 \\
\hline Sucumbios & 1 & 5.4 & 10.35 \\
\hline Orellana & 3 & 5.7 & 15.53 \\
\hline Total & 13 & 10.3 & 23.58 \\
\hline Ecuador & 155 & 15.9 & 28.83 \\
\hline
\end{tabular}




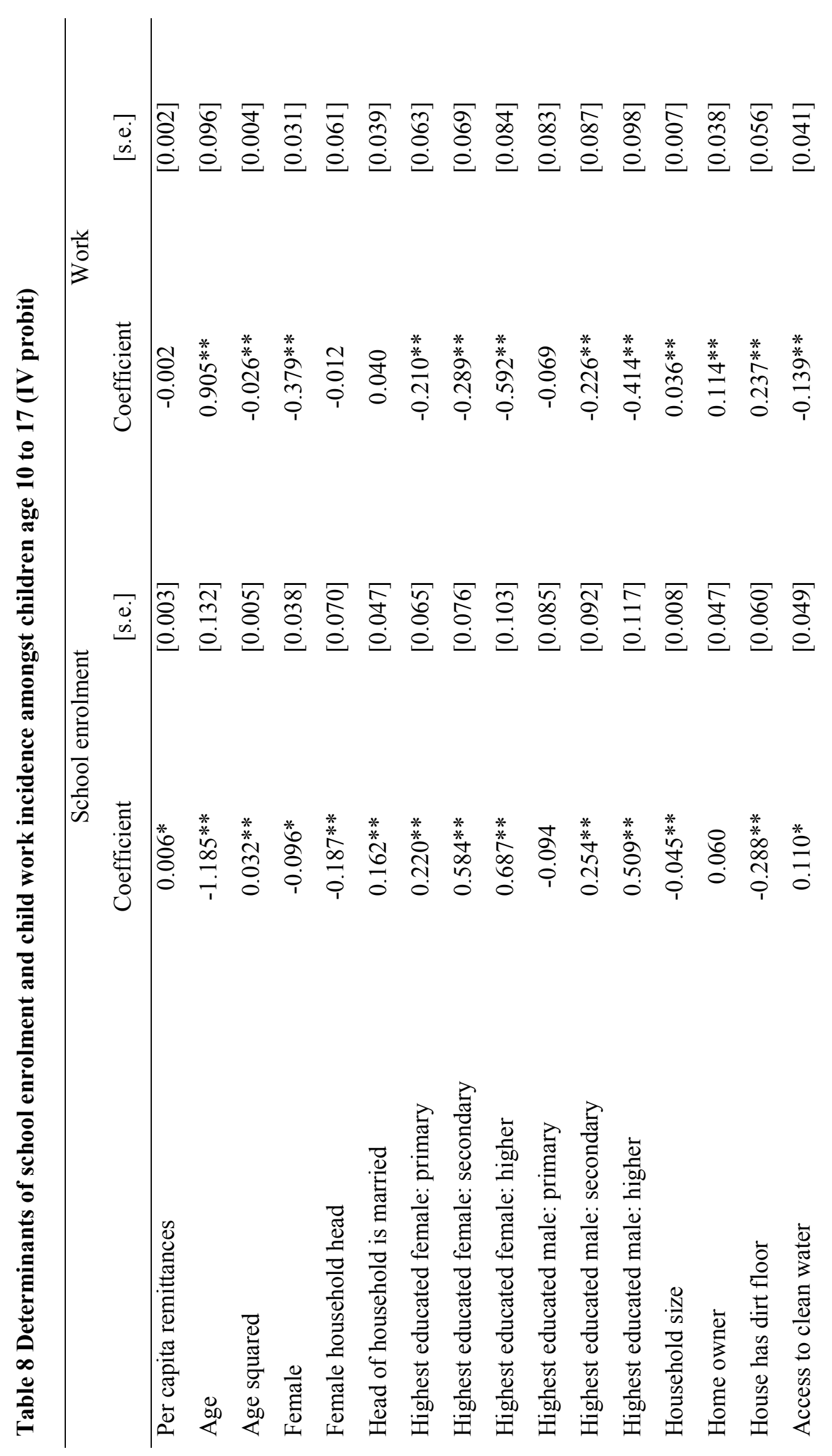




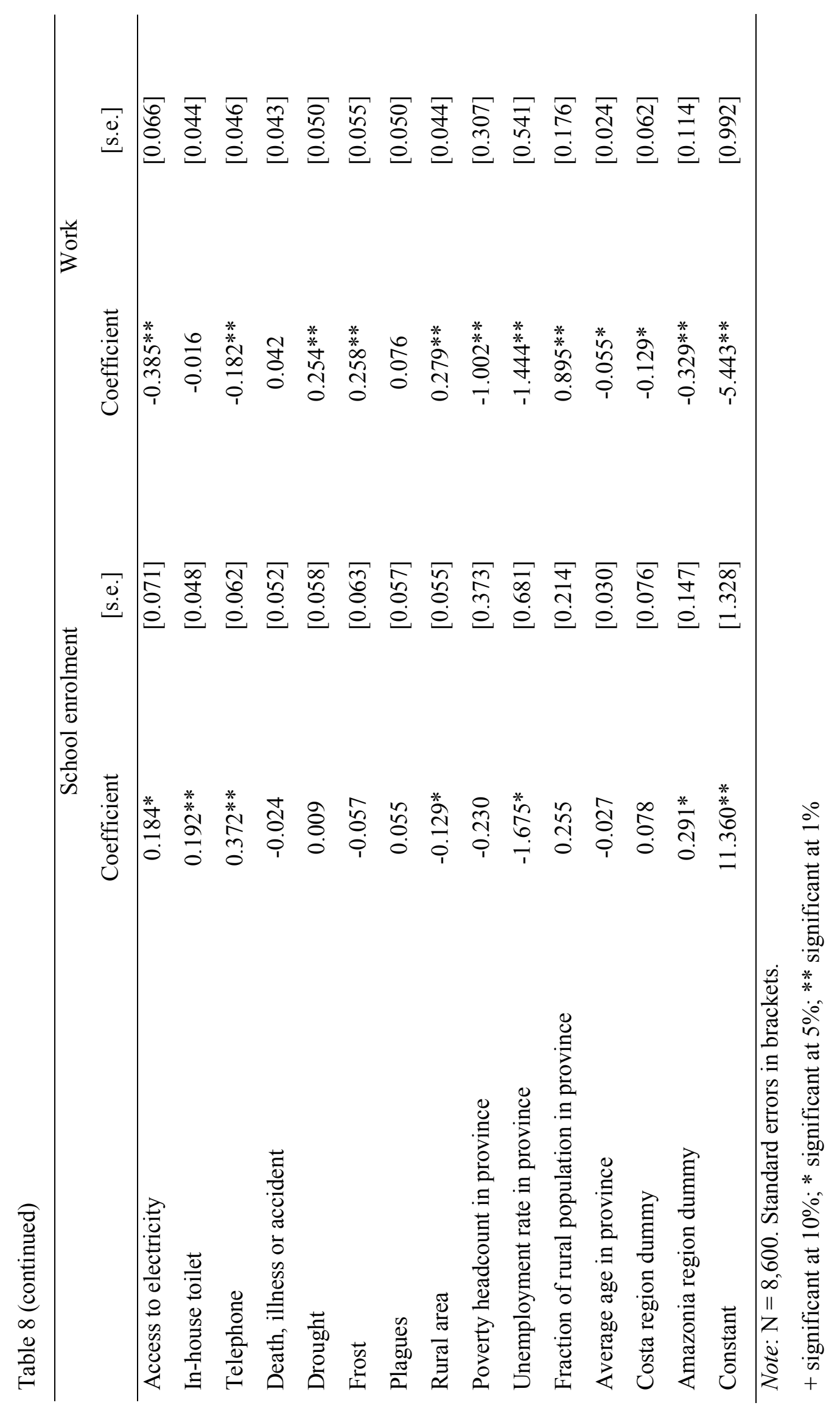




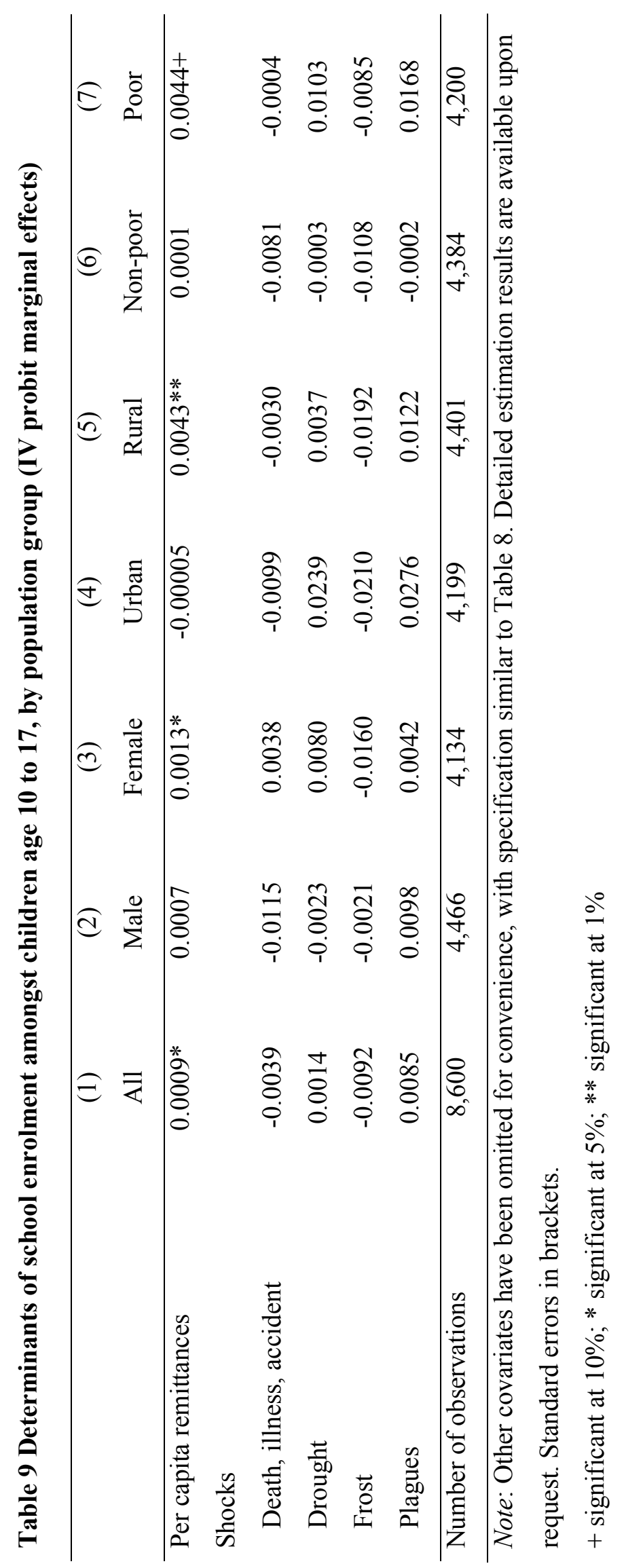




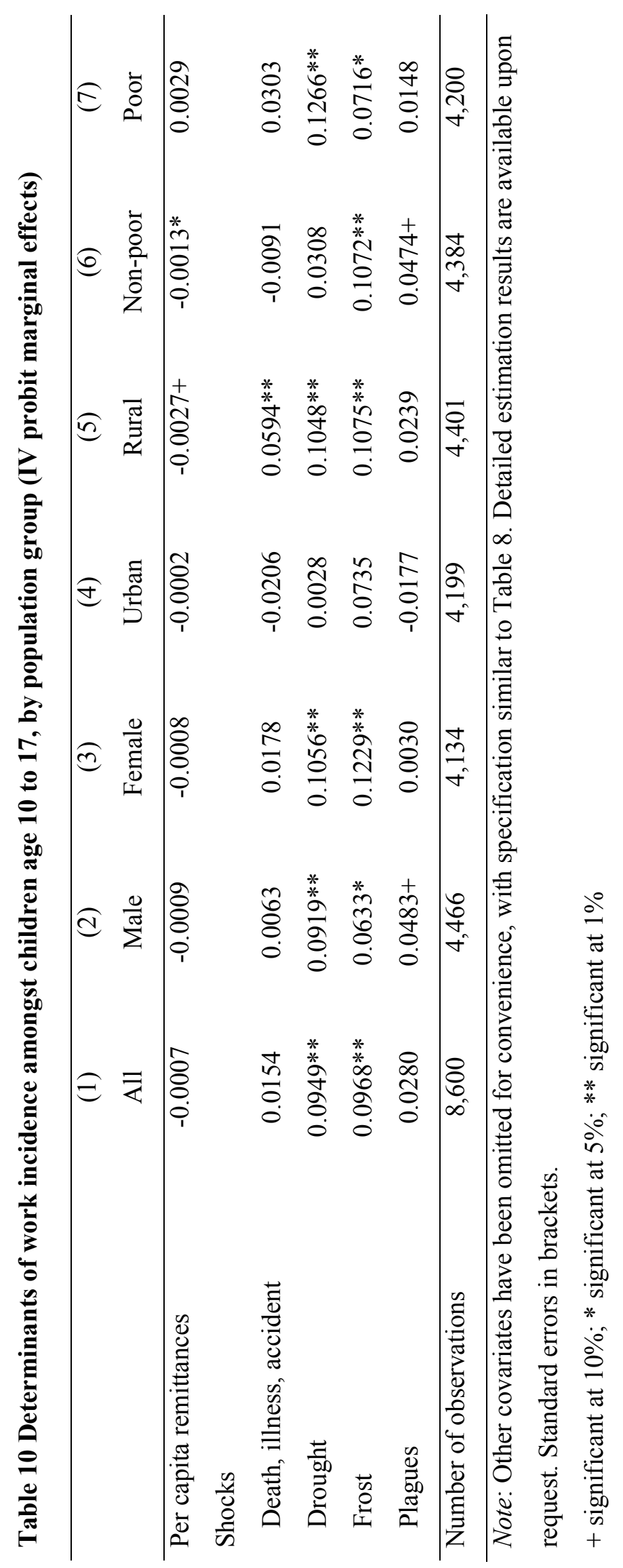


Table 11 Effect of remittances on school enrolment and child work incidence amongst children age 10 to 17 , by type of shock (IV probit marginal effects)

\begin{tabular}{|c|c|c|c|}
\hline & School Enrolment & Work & $\mathrm{N}$ \\
\hline No individual shock & 0.0004 & -0.0011 & 7,253 \\
\hline Individual shock & $0.0026^{*}$ & -0.0004 & 1,347 \\
\hline No drought & 0.0006119 & -0.0010 & 6,664 \\
\hline Drought & $0.0046^{*}$ & -0.0001 & 1,936 \\
\hline No frost & $0.0009+$ & -0.0009 & 7,168 \\
\hline Frost & $0.0033 *$ & -0.0022 & 1,432 \\
\hline No plagues & $0.0007+$ & -0.0004 & 6,870 \\
\hline Plagues & $0.0067 *$ & -0.0030 & 1,730 \\
\hline No aggregate shock & 0.0005 & -0.0009 & 5,996 \\
\hline Aggregate shock & $0.0043 * *$ & -0.0013 & 2,604 \\
\hline \multicolumn{4}{|c|}{$\begin{array}{l}\text { Note: Other covariates have been omitted for convenience, with specification simila } \\
\text { to Table } 8 \text {. Detailed estimation results are available upon request. Standard errors in } \\
\text { brackets. }\end{array}$} \\
\hline
\end{tabular}


Figures

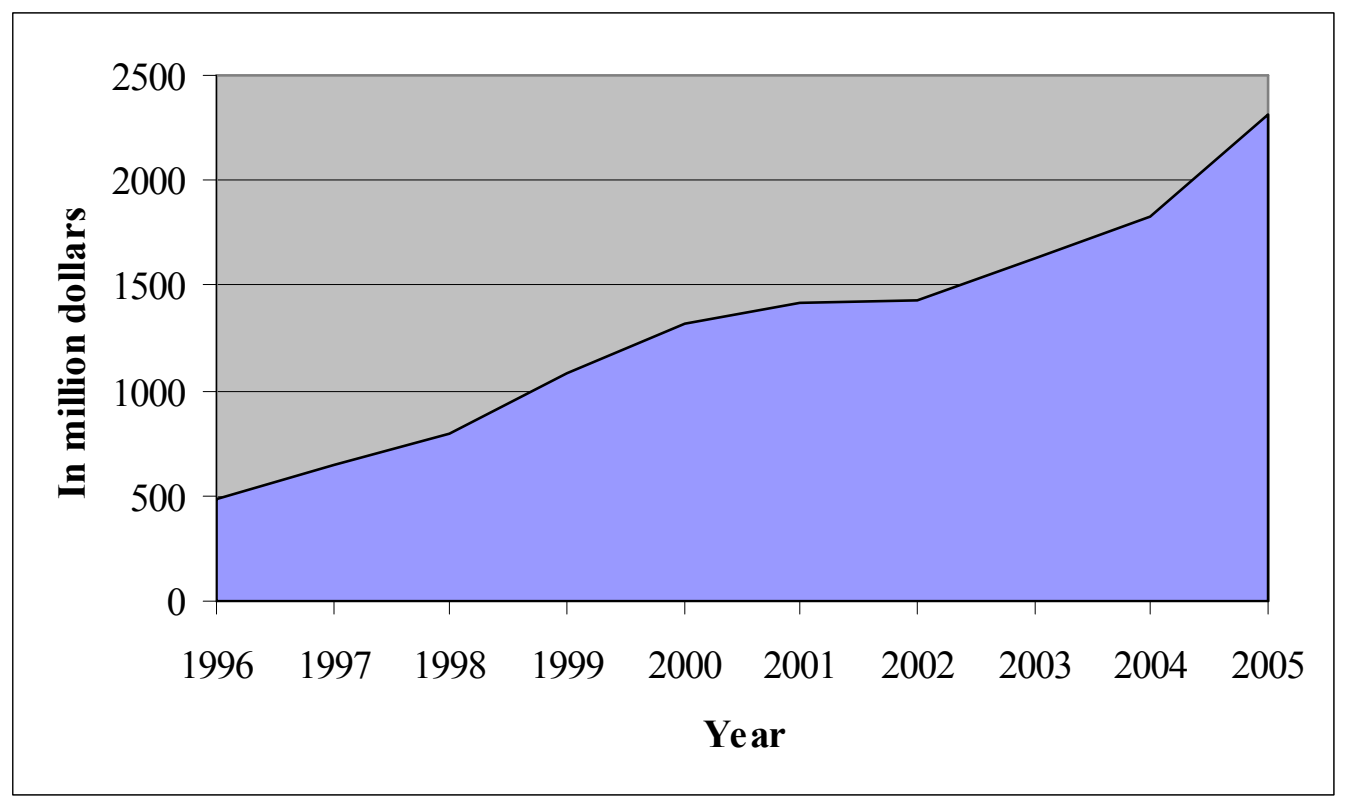

Figure 1 Remittances received in Ecuador from 1996-2005 (million dollars)

Source: Balance of Payments, Central Bank of Ecuador 